\title{
Agriculture and Industry
}

The youngster 1951 had barely arrived when the Beau Geste farms of Oskaloosa sold a Suffolk ewe lamb for a record-smashing price in the United States - $\$ 1,010$. That sale was a harbinger of things to come in lowa during the new year, for before 1951 ran its course, there were abundant signs that the prices for both farm products and industrial goods would continue to rise.

Iowa produced a whopping four billion dollars worth of goods - both agricultural and industrial. The farm parity ratio in Iowa (with the 19101914 modified average of prices as a base) was up 7.5 per cent. Iowa's industrial workers earned over half a billion dollars. Furthermore, these in creases occurred in the face of a comparatively poor corn crop and tightened restrictions in some industrial fields because of the continued war in Korea.

The gross value of manufactured products outstripped Iowa's farm production again - $\$ 2,700$,000,000 in industrial output compared with $\$ 2,372,705,000$ in farm income. But a large por tion of industry's income came from the value added to farm products through manufacturing, such as food processing. 
Corn remained king during 1951 despite a size able drop in corn production caused by a cool, wet growing season and unfavorable fall drying weather. The price of corn remained relatively steady throughout the year. On January 3, March corn brought $\$ 1.76$ a bushel, and on December 30 the price had edged upward to $\$ 1.90$. Production fell to only $471,780,000$ bushels, or considerably below the 1940 1949 average of 533,540,000. Despite this drop, Iowa farmers generally received 17.5 per cent more for their products in 1951 than in 1950, while the prices they paid for goods had advanced only 9.6 per cent during the year. Pork prices proved the exception, however. Hogs brought $\$ 19.75$ per hundredweight top in January, but high receipts forced prices down steadily, with a top of $\$ 17.65$ noted on December 30 .

The 1,800 hard-working employees at Fort Madison's Sheaffer Pen Company got profit-shar ing checks totaling 20 per cent of their first three month's wages. Not so fortunate were employees at Morrell's in Ottumwa, where union representa tives unsuccessfully demanded portal-to-portal pay for their members, plus a paid holiday on the worker's birthday, and a fifteen-pound ham at Christmas! Wages were up throughout the state, however, and the per capita earnings (after taxes) for Iowa were $\$ 1,446$, or slightly above the national average of $\$ 1,423$. This was a per capita increase of $\$ 142$ over 1950. Davenport's per cap - 
ita income of $\$ 2,074$ was the state's highest, a fact which helped erase memories of 1935, when Scott County citizens had an average "spendable income" of $\$ 817$, and ranked second in the state.

Like his city cousin, the Iowa farmer in 1951 used more gasoline, drove more miles in newer automobiles, accumulated more savings, and found more uses for electricity than ever before. Sidney Phelps, a Bayard farmer, built his home without a stairway but installed an electric elevator, along with sixty electric outlets on the main floor. Even with such modern equipment in many homes, the old pioneer spirit of neighborliness still prevailed, as George Schmidt of West Union could testify. When Schmidt's son was fatally injured in a tractor accident, his neighbors pitched in to help with the corn crop. Putting good neighborliness on an international scale, Mrs. Raymond Sayre, of Ackworth, visited with thousands of other farm wives in her globe-circling tour, as president of Associated Country Women of the World, which covered 50,000 miles.

Bank debits increased 12 per cent in 1951. One almost forgotten debt, a 93-year-old mortgage on 31 acres in Cerro Gordo County, was lifted after considerable delay. Department store sales were up slightly, but because of the inflated prices, gains were in dollar volume rather than unit sales. A price war in Cedar Rapids developed at mid-year when several electric appliance dealers declared 
they would not be undersold. Other towns witnessed similar price wars. New Sharon had one which finally ended after regular gasoline sold briefly for 14.4 cents a gallon.

Construction, both residential and commercial, fell off in Iowa during 1951 despite scattered local booms. A shortage of steel and other metals needed for defense production was blamed for the building decline. Notable among the structures which were erected amidst these obstacles were the $\$ 3,000,000$ municipal airport at Waterloo, the Willkie House community center in Des Moines, and the "dream" library at the State University of Iowa. Hard -pressed steel consumers got an in direct promise of more material when the Manchester and Oneida Railroad announced on October 27 it would end fifty years of operation by selling its rolling stock and the entire 8.23 miles of track to salvage dealers.

Iowa livestock won high honors at the Denver and Chicago expositions. Toby, a 1,240-pound Aberdeen-Angus from the Iowa State College farms, was proclaimed the grand champion steer at the International Live Stock Exposition. Cor nelius Wolf of Remsen exhibited Commando, the grand champion steer, at the National Western Fat Stock Show in the Colorado capital. Two teenagers from Hampton, Jay and David Van Wert, probably deserved a blue ribbon for their sow which had a litter of eighteen piglets shortly 
after they paid $\$ 80$ for her. The boys reported a net profit on their project of $\$ 1,237.11$ in less than ten months.

The price of farm land was mounting steadily in 1951 . The average price rose $\$ 15$ an acre, Professor W. G. Murray of Iowa State College reported, to reach a record of $\$ 212$ per acre. The top price for a large farm perhaps was the $\$ 705$ an acre paid near Orange City. A farm journal voiced a discordant note at the rising costs of farm land, which had averaged only $\$ 88$ per acre in 1941. "One of the worst effects of a land boom is what it does to young farmers," Wallaces' Farmer declared. "To keep a healthy agriculture, we need to make it easy for capable young men to start to farm."

When the available farm labor supply grew short in August, 250 natives of the British West Indies were brought to Iowa to detassel corn. Their employers reported they were good workers, but found their British accents somewhat jarring. Displaced persons from Europe also formed a new source of labor for Iowa farms, with most of the $2,563 \mathrm{DPs}$ in Iowa living in rural areas.

Labor in the cities found numerous jobs available with top wages. In June, a new record for workers in nonagricultural pursuits was reached when 620,350 Iowans reported for jobs. Industry had 162,050 workers, of whom 49,350 were em ployed in food processing plants, and 38,000 in 
construction jobs. The Quaker Oats Company at Cedar Rapids experienced some difficulty when workers left their jobs in what the company called a "strike" and the union termed a "lockout." Sporadic labor troubles developed over the state, but these were settled amicably. The days of violence in labor disputes seemed far away. One of Iowa's oldest manufacturing firms, the Maytag company of Newton, produced its seven millionth washing machine during colorful ceremonies which celebrated the opening of a new plant north of the city.

The expected warm, dry weather during Iowa's "Indian summer" was missing, which caused ob servers to predict the corn crop would yield less than final figures indicated. Many farmers had al ready switched to hay in time to produce a profitable yield; by late December nearly seven million tons had been sold or stored, almost half a million tons more than in 1950. Shades of the old west ap peared at Rock Rapids, where cattle rustlers were reported operating in a self-imposed blackout with nearby pickup trucks used for a fast getaway. Hog, sheep, and cattle receipts were well ahead of the 1950 totals, but there were fewer horses and mules on Iowa farms in 1951. Hay, once consigned to work horses and mules, was going to sleek Herefords and Holsteins. The Iowa farmer was doing his work with 239,022 tractors, 44,344 trucks, and 92,881 mechanical corn pickers. 
The horse was on the way out, but one other form of transportation was making a tremendous comeback. Along the banks of the Upper Mississippi deep-throated echoes told listeners that towboats were moving again. In 1951 Colonel Delbert B. Freeman of the United States Army Engineers reported a record twelve million tons of traffic had been transported on the Upper Mississippi, compared with $104,810,855$ tons of freight hauled by the Class I railroads in Iowa. On the Missouri slope, oil men were drilling a "wild cat" near the Little Sioux River in Harrison County. No flowing gushers were reported in sight, but the increased activity in the Williston Basin in North Dakota seemed to have stimulated test drilling in western Iowa.

The full dinner pail and the growing bank account furnished evidence that Iowa industry and agriculture found 1951 deserving of that warm phrase - as the Parkersburg Eclipse put it - "a good year." But the war in Korea had affected management, labor, the farmer, the housewife; and perhaps no year when America's young men are called to battle deserves the unqualified title of "a good year." Nevertheless, 1951 was a year when Iowa and America continued to expand and develop. And if 1951 was not a year of peace, it was at least a year of plenty.

Robert Rutland 